\title{
Zdroj politické neúčinnosti pedagogické komunity: Nesounáležitost praktiků a teoretiků
}

\author{
Radim Šíp \\ Masarykova univerzita, Pedagogická fakulta, Katedra sociální pedagogiky
}

\section{Systémová nesounáležitost: předběžné poznámky}

V tomto textu nenabídnu nový, překvapující model vztahu mezi praxí a teorií, jakým byl např. model Vladimír Spousty v diskusním příspěvku posledního čísla Pedagogické orientace (srov. Spousta, 2013, s. 112-125). Naopak z teoretické roviny sestoupím do každodenní profesní a politické ${ }^{1}$ praxe, pro kterou je charakteristická nespolupráce mezi praktiky a teoretiky a dalšími aktéry školské politiky. Poukážu na to, jak by proměna této praxe mohla zkvalitnit práci pedagogů a zajistit jim větší společenské i politické uznání a tím i silnější vyjednávací pozice.

Sounáležitost je v tomto textu vnímána jako vlastnost společenského života, jejíž existence je podmínkou pro kolektivní vyjednávání společných ideálů a cílů a procesů jejich dosahování. Mluvíme-li o sounáležitosti jako o hodnotě, která nám chybí, pak zároveň popíráme účinnost neoliberálních představ stejně jako představ etatistické nadřazenosti politicko-byrokratického aparátu ostatním aktérům. Podle apologetů neoliberalismu se společnost má projevovat tak, že svobodné aktivity jednotlivých aktérů samy o sobě budou vést ke vzniku nějaké společenské oblasti a $\mathrm{k}$ její samoorganizaci. Taková „Svobodná" samoorganizovanost bude údajně nejlépe odpovídat potřebám společnosti. Podle přesvědčených etatistů je to stát prostřednictvím svého úřednického aparátu a expertních skupin „vyvolených“, který analyzuje situaci, zkonstruuje systém nápravy (např. reformu) a implementuje ji do života společnosti.

Oba př́stupy marginalizují sílu a vliv jednotlivých aktérů. Neoliberální model oslabuje sociální pouta natolik, že jednotliví aktéři se stávají sociálně a politicky naprosto neakceschopní, a tak zranitelní a zneužitelní lobbistickými skupinami. Etatistický model činí to samé tím, že aktérům ve svém důsledku

1 Slova politický budu $\mathrm{v}$ tomto textu používat $\mathrm{v}$ jeho širším významu, jako adjektivum naznačující politický tlak profesních a občanských iniciativ, které jsou činěny za účelem změny nastavení v jednotlivých politikách státu. 
upírá svobodnou aktivitu, a proto i v tomto konceptu jsou praktici a teoretici nakonec také vystaveni nadvládě lobbistických systémů, které dříve nebo později ovládnou jednotlivé buňky příslušných ministerstev. V naší politické realitě posledních dvaceti let oba extrémní přístupy utvořily zvláštní symbiózu postupného oslabování role státu, které je (paradoxně?) doprovázeno čilou, nicméně velice nákladnou a neúčinnou byrokratickou aktivitou ministerstev. Tato symbióza není za mlhou ideologických „střetů“ téměř vidět. Snad proto upadáme do „blbých nálad“ a nehledáme účinné nástroje, pomocí kterých bychom tuto prapodivnou koalici velkých slov a nefungujícího jednání dokázali dešifrovat, odhalit a odstranit.

Oblast školství je dokonalým modelovým příkladem existence této koalice a jejího fungování. Úkolem mého diskusního příspěvku však není navrhnout systémovou změnu, ale poukázat na to, co je politickou podmínkou přetrvávání systémové nesounáležitosti mezi praktiky, teoretiky, úředníky a politiky, a také na to, jak se nesounáležitost promítá do každé události - v našem případě je za modelovou událost zvolen průběh příprav a implementace kurikulární reformy.

\section{2 Školská politika státu}

Ve svém textu Jiří Pelikán (2012) vyjádřil myšlenky, které pojmenovávají problematické momenty českého školství a $\mathrm{v}$ mnohém souzní s mým pohledem. Chtěl bych zde především zopakovat centrální myšlenku jeho textu: stát se nemůže a nesmí vyvléci z povinnosti vyjednat a veřejně deklarovat školskou politiku prostřednictvím základního dokumentu o dlouhodobém směřování českého školství (tamtéž, s. 583-584). Z této povinnosti se již téměř dvacet let úspěšně vyvléká - žádný dokument s takovým či podobným názvem „Dlouhodobá strategie směřování českého školství: 1999-2040“ neexistuje. At' už je skutečným důvodem tohoto stavu cokoli, role státu je fakticky oslabena a politika školství se stává neustále se proměňujícím polem ideologických svárů.

Nevím o žádné aktivitě poslance či senátora, který by se za posledních dvacet let pokusil vyjednat napříč parlamentem výše zmíněný politický dokument. Je to zvláštní, nebot' teprve takový dokument by připravil politické a odborné prostředí, v němž by další, již odborně profesní práce (např. Bílá kniha), našly bezpečně vykolíkované hřiště pravidel a závazků. Jedině takový obecný politický konsensus může být přímo či nepřímo dlouhodobým garantem 
stejných cílů, pravidel, a tedy i stability pro politické strany, úředníky, učitele, reformátory, studenty, žáky a jejich rodiče.

Jelikož nemáme takový dokument, potácí se naše školství od jedné „priority“ ke druhé, od jedné „systémové změny“ k jiné, a nyní se dokonce zdá, že od jedné reformy - kurikulární - k reformě s odlišnými ideovými východisky - k reformě ke „konkurenceschoposti“. Do takového stavu jsme se nedostali primárně proto, že bychom měli špatné učitele nebo málo vzdělané žáky, jak se nás snaží přesvědčit velká část českých médií, ani proto, že naši úředníci jsou více sobečtí než úředníci v jiných zemích. Neutěšený stav je zapřičiněn tím, že zde po téměř dvaceti letech nemáme kariérní řád učitelů, systematicky ukotvené další vzdělávání pedagogických pracovníků a jejich náležité finanční ohodnocení. Je zapříčiněn také tím, že po dvaceti letech nejsou jasně stanoveny standardizované základní vzdělanostní úrovně, které žáci a studenti musí dosáhnout, chtějí-li se ucházet o vzdělávání na vyšších stupních. A konečně také tím, že úředníci nemají jistotu stability prostředí, díky níž by byli schopni a ochotni čelit přiliš politickým rozhodnutím svých ministrů a náměstků. Proto vyhledávají útočiště v lobbistických skupinách, které jim alespoň dočasně garantuje to, co by měl dlouhodobě dělat stát jasné nasměrování a udržitelnost jejich cílů a priorit.

Přesně tyto věci měly být ve výše zmíněném politickém dokumentu rámcově vyjednány a měla zde být deklarována politická vůle všech zainteresovaných vyjednaného $\mathrm{k}$ daným termínům dosáhnout. Za takové podmínky by úředníci byli vázáni tímto dokumentem více než okamžitými politickými rozhodnutími. Existence takového dokumentu by samozřejmě pro politika znamenalo výrazné omezení jeho manévrovacího prostoru. A to je mu z pochopitelných důvodů nepř́ijemné (čest výjimkám). Navíc by to otevřelo nutnost veřejně a závazně odpovědět na otázky: Skutečně chceme, aby naši spoluobčané byli vzdělaní? Pokud ano, jaké prostředky je k tomu nutné použít? Kolik musíme investovat?2 Jaký by měl být vztah mezi státními školami a soukromými školami na primárním, sekundárním a terciárním stupni? Proč by takový měl být? Je nutné stanovit nějaké vymahatelné vzdělanostní standardy jednot-

Poměr mezi rozpočtem resortu MŠMT a ročním HDP klesá: v roce 2010 3,29\% (viz Rozpočet kapitoly MŠMT na rok 2010), v roce 2012 3,15 \% (viz Rozpočet kapitoly MŠMT na rok 2012). Ještě v rozmezí let 2000-2002 byl poměr rozpočtu k HDP 4,4 \%. Už tehdy jsme ale o celé dvě procenta zaostávali za Finskem, které je příkladem skutečně úspěšné investice do vzdělání, a tedy i skutečně úspěšné, systémové a dlouhodobé reformy školství (srov. Education statistics... a OECD, 2011, s. 117-136). 
livých stupňů? Pokud ano, jak se budou zjištovat a jak se bude trestat jejich nedosažení? Atd.

Málokterý český politik dnes přistoupí na takové omezení své moci. Měli bychom se smírit s tím, co je v zahraničí běžné. Politiky k takovému systémovému jednání budeme muset donutit naší profesně politickou aktivitou. Abychom však byli dostatečně silnými partnery, musí být všichni aktéři školské politiky schopni vzájemné spolupráce na profesní i politické rovině - přičemž spolupráci mezi praktiky a teoretiky vnímám jako stěžejní. To od nás mimo jiné bude vyžadovat, abychom překonali překážky, které si pedagogika uvnitř svého oboru vytvořila $\mathrm{v}$ době, kdy se etablovala jako věda. Jednou $\mathrm{z}$ hlavních překážek je vnímání zásadní odlišnosti mezi tzv. „praktickou pedagogikou“ a tzv. „vědou o výchově" (logiku vzniku této hranice viz Brezinka, 2001, s. 15-47). Toto rozdělení oboru se přenáší i na jednotlivé aktéry, které více méně odděluje - učitele-praktiky od teoretiků z VŠ a výzkumných ústavů.

\section{Systémová nespolupráce}

Na poslední konferenci ČAPV si během vyžádané zahajovací přednášky profesor Průcha postěžoval, že pedagogické výzkumníky a teoretiky nebere decizní sféra dostatečně vážně, ale že bychom se tím neměli nechat znechutit a „dál dělat svou vědu“ (srov. textovou podobu původní přednášky - Průcha, 2012). Při vší úctě k obdivuhodné celoživotní práci Jana Průchy jsem na toto prohlášení zareagoval. Přestože to patrně nebylo Průchou takto míněno, mohl jeho povzdech svádět k interpretaci, že teoretik či výzkumník je zde od toho, aby pracoval ve svém oboru a nezajímal se o otázky, které s jeho výzkumem přímo nesouvisí - tedy i otázky týkající se uplatnění jeho teorií. Takový výklad považuji za velmi nebezpečný, a proto jsem se proti němu ohradil. Pokusím se nyní přesněji artikulovat, co jsem se tehdy snažil pojmenovat.

Profesní nezralost české pedagogiky se projevuje v tom, že jsme ochotni dělat „vědu“ bez ohledu na skutečnou praxi a „praxi“ bez ohledu na skutečnou vědeckou reflexi. Jedná se o nezralost nejenom z toho důvodu, že trpí skutečná věda stejně jako skutečná praxe, ale především proto, že pedagogové-praktici a pedagogové-teoretici jsou nejpřirozenější partneři. Jedině prostřednictvím jejich spojení jsme schopni dojít k proměně českého školství, a to jak na profesní úrovni, tak na té druhé - na úrovni politické (v onom výše zmíněném širokém slova smyslu). Politická úroveň výrazně ovlivňuje přístup a chování významných reprezentantů z jiných sfér. Jedině v tomto 
spojení jsme schopni umocnit naše znalosti a požadavky natolik, aby tuto zprávu zaslechla nejen veřejnost utápějící se v „blbých náladách“, ale také sféra decizní, která řeší „své“ problémy.

Právě v tomto naprosto selháváme. Nemáme společné platformy, které by nás přivedly $\mathrm{k}$ upř́mnému dialogu mezi praktiky a teoretiky. Z vysokých škol vycházejí absolventi, kteří toho př́liš nevědí o tom, co od nich společnost očekává, jak je bude dlouhodobě hodnotit a jaké podmínky jsou na pracovištích těmito požadavky a hodnocením generovány. Absolventi pak mají plno ideálů (často velmi naivních), jak změnit příliš „konzervativní“ pedagogickou „realitu“. Na základní a střední školy jsou absolventi přijímáni s pochopitelnou nedůvěrou a jakákoli snaha elévů o pozitivní změnu je velmi často přidušena hned $\mathrm{v}$ zárodcích. Za této situace se $\mathrm{z}$ bývalých absolventů často stávají kverulanti a posléze ti, kteří přijmou svoji roli a svoji zášt' obrátí vůči své alma mater. Vyučující na vysokých školách jsou přirozeně kritiky stylu výuky na základních a středních školách, ale vedle oprávněných důvodů zde také hraje svoji roli podvědomý pocit, že za daných podmínek nejsou schopni své absolventy připravit lépe na jejich profesi. Ti, kteří se snaží změnit výuku směrem k hlubší reflexi reality na školách, brzy narazí na institucionální hranice a cítí se být „veverkami v kleci“.3 Tyto dva tábory mezi sebou vedou nevyřčenou válku, jež je hluboce zakotvena v jejich nevědomí a jež - ku neprospěchu obou stran - se promítá do jejich neschopnosti ukázat veřejnosti, že jim o něco skutečně podstatného jde, a decizní sféře, že tady mají silného partnera, který ví, co chce, má znalosti a prostředky, jak toho dosáhnout, a je proto nutné s ním pozorně vyjednávat.

Když jsem se blíže zabýval průběhem a výsledky kurikulární reformy, uvědomil jsem si, že právě zde máme modelový příklad systémové nespolupráce. Nebot' způsob, jakým byla kurikulární reforma připravována, ověřována a zaváděna charakterizuje klasický průběh nespolupráce mezi praktiky, teoretiky, reformátory a decizní sférou. Významnou informací je také to, že všichni aktéři této reformy - dokonce i její autoři - byli obět'mi nesystémovosti

\footnotetext{
„Veverky v kleci“ je metaforické vyjádření stavu, kdy jsou vysokoškolští pedagogové zaměstnáváni stále více povinnostmi, které stále méně odpovídají jejich hlavnímu poslání - připravit další odborníky v daném oboru. Čím více se za takové situace snaží zvládat práce, aby tak našli prostor pro kvalitní vzdělávání svých studentů, tím více jim přibývá povinností, které je ještě více odvádějí od jejich povolání. Jsou veverkami v kleci, které zcela nesmyslně a ke své škodě roztáčejí kolo institucionálních povinností. K tomu blíže viz Šíp (2012).
} 
a nespolupráce. Bývalí členové Výzkumného ústavu pedagogického (VÚP) ${ }^{4}$, který byl $\mathrm{v}$ době př́prav a spouštění reformy jedním z výkonných orgánů MŠMT, neměli zjevně od svých nadřízených dostatečnou podporu. Např. Jan Tupý poznamenává na námitku, že kurikulární reforma byla nedostatečně na školách vysvětlena: „Je na místě připomenout, že model propagace kurikulární reformy, připravený VÚP a NÚOV v roce 2005, byl zamítnut... Velký problém spatřuji i v malé podpoře aktivit, které by v širším měřítku umožnily výměnu zkušeností z tvorby ŠVP..." (Tupý, 2011, s. 488). Na jiném místě se zase dočteme komentář k poznámkám o nekoncepčnosti zavádění reformy: „... Současně je tvůrcům RVP často předkládána (shora i zdola) odpovědnost za něco, co nemohli ovlivnit, i kdyby chtěli, protože na to nemají kapacitu, prostředky, čas, pravomoci a nikdo jim to nezadal..." (Tupý, 2011, s. 491).

Systémově nahlédnuto i reformátoři samotní byli - podobně jako praktici a teoretici - obětí reformy. Vedle nedostatečné podpory ze strany zadavatele úkolu - tzn. MŠMT - selhávala i zpětná vazba. V tehdejším systému (podobně jako $\mathrm{v}$ tom dnešním) neměl téměř nikdo z praktiků možnost zavčasu reformátorům říci, že reformě nerozumějí, že nerozumějí nejen základním pojmům, ale i celkovému směřování. Nikdo neměl možnost vyžadovat od reformátorů data o negativech dosavadního českého školství, na základě kterých byla idea reformy koncipována, přestože právě taková data by byla schopna ono porozumění zprostředkovat. Stejně tak neměl téměř nikdo možnost udělat nezávislou analýzu návrhu reformy ještě před tím, než byl spuštěn její pilotní provoz. Teoretikům $z$ vysokých škol bylo umožněno skutečně významnější zhodnocení reformy teprve poté, co reforma opustila pilotní školy a vydala se „do světa“. ${ }^{5}$ Pokud se zde objevily odborné pochyby o motivacích, zakotvení a směřování české kurikulární reformy (viz např. Štech, 2006), zůstaly téměř nepovšimnuty a hlavně nezohledněny $\mathrm{v}$ dalším rozvíjení příprav a průběhu reformy.

Praktici však teoretiky považují za spoluodpovědné za nedotaženou reformu. Jak jsme právě naznačili - z velké části neoprávněně. Přesto je reakce praktiků pochopitelná. Zaprvé nejsou př́liš zpraveni o tom, jaké jsou vztahy mezi teoretiky, reformátory a decizní sférou (mimochodem, jedná se také o projev

4 V červnu 2011 došlo ke sloučení VÚP s NÚOV (Národním ústavem odborného vzdělávání) a IPPP (Institutem pedagogicko-psychologického poradenství) a tyto tři organizace MŠMT vytvořily nástupnickou organizaci Národní ústav pro vzdělávání, školské poradenské zařízení a zařízení pro další vzdělávání pedagogických pracovníků (NÚV).

5 K výsledkům takového kritického zhodnocení ex post viz např. Janík et al. (2011). 
komunikačního nesouladu). Zadruhé jim pochopitelně splývají, nebot' se jich v podstatě ani jedna skupina nezastala poté, co velice svérázně a věcně nesprávně začala česká média interpretovat výsledky PISA testů. Mnohá z nich tehdy tvrdila, že za pokles „,konkurenceschopnosti“6 českých žáků může „neochota a lenost českých učitelü“, která se mimo jiné projevuje v jejich nepřijetí kurikulární reformy. Že se reforma ke „konkurenceschopnosti“ na straně jedné a reforma kurikulární na straně druhé, alespoň jak jsou dosud nastaveny, téměř vylučují či popírají a že tedy primárně chyba nebude $\mathrm{v}$ „líných učitelích", nikdo nezmínil. Stejně tak téměř nikdo neocenil praktiky, kteří udělali mnoho práce vzhledem $\mathrm{k}$ tomu, jak málo jim byla důležitost reformy vysvětlena, jak nesystémová a nedostatečná byla institucionální podpora a jak málo mohli být řediteli odměňováni za aktivní př́ístup k vytváření ŠVP. Podobně málokdo ocenil ředitele, kteří se rozhodli přesvědčovat své podřízené, že reforma je nutná, potřebná a bude mít výsledky, a proto je nutné se jí zúčastnit, přestože jim nemohou nyní nabídnout ani výraznou institucionální podporu, ani odpovídající finanční ohodnocení (k tomu viz Kuhn, 2011; o něco skeptičtější pohled viz Hrubý, 2011). Tato situace nakonec ještě více posílila pozice skeptikủ v řadách učitelů, kteří již dávno předtím tvrdili (a bohužel často oprávněně), že jakákoli snaha něco zlepšit se vždy obrátí v neprospěch těch nejníže - v neprospěch učitelů. Samožrejmě se to obrací i v neprospěch žáků a celé společnosti, ale o tom skeptici často nemluví.

\section{Reforma a kompetence}

Úspěšnou kurikulární (stejně jako jakoukoli jinou velkou) reformu můžeme uskutečnit teprve tehdy, když bude předem zodpovězeno mnoho otázek, o kterých se u nás veřejně začalo mluvit, až když byla reforma spuštěna a o její účinnosti se začalo veřejně pochybovat. Jde například o otázky: Chceme školství decentralizovat? Pokud ano, jak to lze skloubit s potřebou standardizace znalostí? Chceme naše žáky učinit konkurenceschopnými na světovém trhu práce? Pokud ano, jak se to dá propojit s odpověd'mi na předcházející otázky? Může nám k těmto cílům dopomoci radikální změna kurikula? Co je její centrální bod? Znalosti, dovednosti a hodnoty nebo kompetence? Jak konkrétně kompetence vedou či mohou vést ke konkurenceschopnosti?

6 V PISA testech nešlo o testování konkurenceschopnosti, ale v té době se slovo „konkurenceschopnost" stalo velice módním, a tedy snadno „vytěžitelným“ a zneužitelným slovem. Zvláště pro některé lobbistické skupiny. 
CO KONKRÉTNĚ se míní „otevřeným kurikulem“, „kompetencí“, „konkurenceschopností"? A JAKÉ KONKRÉTNÍ důsledky mohou mít tímto způsobem pochopené základní pojmy a cíle? Takto konkrétně to nikdo nespecifikoval, a tak se vytratila jasná návaznost na každodenní praxi a na její prospektivní proměnu.

Přestože kurikulární reforma neměla pouze jediný cíl a „kompetence“ nebyla jediným centrálním pojmem, využijeme v následujících odstavcích právě tento pojem jako modelový př́klad systémové nespolupráce. Díváme-li se do dokumentů kurikulární reformy, jsme svědky teoretické a estetické práce $\mathrm{s}$ pojmy bez vykazatelných vztahů $\mathrm{k}$ reálnému procesu výuky. $\mathrm{V}$ lepších případech konkrétní odkazy k reálnému procesu najdeme, ale skutečný vztah ke kompetencím, tak jak byly koncipovány v kurikulárních dokumentech, postrádají. Příkladem této druhé, lepší varianty je text Klíčové kompetence ve výuce na základní škole a gymnáziu (Klíčové kompetence..., 2011). Zde je vedle dalších představena „výuková situace“: „W. Shakespeare: Romeo a Julie. Lepíková diskuze - ,internetová diskuze bez internetu“" (Klíčové kompetence..., s. 10-16). Je složena ze dvou částí. V první z nich se probírají klíčové kompetence, které by měly být výukovou situací rozvinuty, a výchovné a vzdělávací strategie, kterými by měli žáci $\mathrm{k}$ tomuto cíli projít. Přesně tato část se pohybuje $\mathrm{v}$ povinném světě éterického, ke všemu a k ničemu zavazujícího kompetenčního ptydepe (srov. Klíčové kompetence..., s. 10-13). Zbytek je věnován daleko zajímavější a pronikavější části, která nabízí velmi dobře propracovanou metodiku hodiny. To, co je hodnotné na celém snažení, je právě ona metodická část, která mimo jiné ukazuje, že snaživí a dobří učitelé rozvíjejí zmíněné „,kompetence“, aniž by z nich museli dělat podstatu své práce, a tak odvádět pozornost od reálně zhodnotitelných procesů výuky ${ }^{7}$. Pokud ale chceme od vyučujících víc, pak musíme jasně vysvětlit, proč tento vztah mezi kompetencí a metodikou artikulujeme. Vedou kompetence, tak jak jsou vágně definovány v kurikulárních dokumentech, k lepšímu životu? Jak se to projevuje v realitě? Je to možné nějak empiricky prokázat? Je nějaký způsob, jak hodnotit dosažení určité hladiny klíčové kompetence? Lze takové hladiny vůbec vymezit? Atd. Ani na jednu z těchto otázek dodnes nedostali praktici uspokojivou odpovědět.

Těsně před svým zrušením (sloučením) začal VÚP poskytovat metodické příručky a další materiály. Dáme-li stranou matoucí pasáže o kompetencích a jejich rozvíjení, pak máme po ruce centralizovanou a snadno dostupnou banku metodických nápadů a př́kladů k seberozvíjení učitelské kondice, kterou učitelé již dávno potřebovali ke své inspiraci a vzájemnému sdílení svých zkušeností. (Dnes je mnoho podobných textů k nalezení na www.rvp.cz.) 
Kdyby zde ale existovala systémová možnost vzájemné a upřímné spolupráce mezi praktiky na jedné straně a teoretiky a reformátory na straně druhé, bylo možné zavčasu odhalit nereálná očekávání a reformu pozastavit, rekonstruovat a zachránit. Praktická nepoužitelnost jednoho z centrálních pojmů - „kompetence“ - by mohla být snadno odhalena za předpokladu, že by vyučující z praxe měli ještě pred zahájením reformy právo a možnost od reformátorü ${ }^{8}$ vyžadovat, aby jim detailně specifikovali, jak konkrétně se nový pojem „kompetence“ promítne do reality vyučování. Za předpokladu, že by se mohli ptát a čekat konkrétní odpovědi na otázky: Jaký uchopitelný vztah je mezi tou a tou kompetencí na jedné straně a mezi těmi a těmi znalostmi a dovednostmi na straně druhé? Jak nás mohou odlišné soubory předávávaných znalostí a dovedností dovést ke stejným kompetencím (např. řešení problémů $\mathrm{v}$ matematice a $\mathrm{v}$ řešení problému během literárního rozboru textu)? Jak se dá dosažení kompetence zjištovat či testovat? Hrají v tomto procesu nějakou roli znalosti a dovednosti, jejichž dosažení alespoň zhruba zjištovat a testovat dokážeme? Jak může důraz na kompetence podpořit decentralizaci systému školství, aniž by to narušilo jeho prostupnost a zajištění standardů obsahu učiva? Atd.

Opět se zde dotýkáme zmíněného nedostatku českého školství - neexistence debaty mezi praktiky, teoretiky, reformátory a úředníky. Kdyby výše zmíněná férová debata a následné vyjasňování proběhly, velice záhy bychom přišli na to (na co reformátoři stejně později začali více a více narážet), že nám pojem „kompetence“ definovaný tak, jak byl formulován v kurikulárních dokumentech, nakonec $\mathrm{v}$ ničem nepomůže, nebot' nemáme reálné nástroje, jak detekovat rozvíjení tak široké a všeprostupující „dovednosti“, jakou je např. „kompetence $\mathrm{k}$ řešení problému“9. Teprve za takových okolností bychom se mohli společně přesunout od světa teorie vystavěného na mlhavé úředně-politické poptávce ke konkrétním otázkám: 0 co nám vlastně jde? O decentralizaci systému? Jakby měla decentralizace vypadat, aby státzároveň

8 Popř́padě i od teoretiků, pokud by ovšem oni měli reálnou možnost podílet se na přípravě reformy.

9 Po dlouhých debatách s Tomášem Janíkem a jeho doktorandy (např. Veronikou Lokajíčkovou či Terezou Češkovou) jsem v poslední době změnil svůj původní názor, že kompetence jsou naprosto zbytečným termínem. Uvědomil jsem si, že by jej bylo možné využít pro pojmenování komplexní pedagogické „zdatnosti“ či „kondice“, která vychází z z dispozic jedinců, jež jsou náležitě rozvíjeny ve vztahu k té které problematické situaci, přičemž jsou v tomto rozvíjení náležitě kombinovány teoretické a praktické znalosti, dovednosti a návyky. Taková kompetence však nemůže hrát základní evaluační roli v kurikulární reformě. 
dokázal garantovat prostupnost systému a základní úrovně vzdělávání? Jde nám o nové pojetí kurikula? V čem konkrétně by mělo být jiné? V nových obsazích? Pokud ano, jak, proč a kým budou určovány? V nových metodách výuky? Které, proč a kdy budou preferovány? Kurikulum by mělo být jiné v mezioborové integraci předávaných/utvářených poznatků? Pokud ano, jak reálně může být taková výuka zahrnuta do současného školství, které je organizované striktně oborově? Jaké standardy budeme sledovat a vyžadovat a proč? Atd. A především: Jak se konkrétně bude vyhodnocovat úspěšnost reformy? Za splnění jakých parametrů budeme moci říci: Reforma byla úspěšně navržená a úspěšně implementovaná?

Každá z těchto otázek vyvolává otázky další a snahy po jejich konkrétním zodpovězení by nás vedly k uvědomění si složitosti a provázanosti systému. Už bychom se nemohli chytat vějiček mlhavých teoretických pojmů („,kompetence“, „,konstruktivní škola“, „projektové vyučování“ atp.), ale museli bychom brát vážně každý krok reformy a jeho důsledky vyvažovat tím, co ze starého systému potřebujeme zachovat, aby se nám v rukou nerozpadl. Instruktivní je zde př́klad zdánlivě nenápadné otázky: Jak může být výuka integrovaných předmětů reálně - nikoli jen jako výjimka, ale jako inherentní princip problémového vzdělávání - zahrnuta do současného systému, když je školství organizované striktně oborově? Kdyby byla tato otázka skutečně položena, odpověd' na ni by nás dovedla k uvědomění, že je nemožné žádat po učitelích základních a středních škol, aby bez jakékoli institucionální podpory a finanční motivace "vystavěli“ integrované předměty a vyučovali je, jestliže samotná edukace budoucích učitelů na vysokých školách je založena na př́ípravě úzce profesně vymezených specialistů. Přičemž úzce vymezenými specialisty není obvykle míněna odbornost ve smyslu pedagogickém či didaktickém - tedy, že absolventi těchto vysokých škol umí předávat poznatky speciálních věd v takové míře, souvislosti a formě, aby byly pro jejich budoucí žáky přijatelné, zařaditelné do př́slušného horizontu života, a tak nakonec i využitelné. Má se tím často na mysli především to, že studenti pedagogických oborů by měli být především specialisty v oboru, přičemž didaktická zdatnost je považována za pouhý doplněk výbavy budoucího učitele.

Celá tato úvaha nás přivádí k významné skutečnosti, která při př́ípravě reformy nebyla dostatečně zohledněna. Ještě před takto koncipovanou reformou na základních a středních školách mělo nejprve dojít $\mathrm{k}$ významné reformě na fakultách, které připravují budoucí učitele. Doufejme, že vůdčí osobnosti 
nakonec pochopí, že právě zde vězí klíč k rehabilitaci pedagogických fakult. Rehabilitace může spočívat jedině v tom, že jejich absolventi budou odborníci především v didaktickém pojetí vystudovaných oborů a že tento didaktický zájem bude svou orientací na faktické prožívání, zakoušení a chápání reality žáky na základních a středních školách snáze generovat interdisciplinární hledisko ve výuce. Tímto způsobem by pedagogické fakulty mohly společnosti ukázat, že jsou speciální a nenahraditelné.

Možná že by se nakonec v reálné diskusi mezi praktiky, teoretiky, reformátory a úředníky ukázalo, že provést skutečně důslednou kurikulární reformu by si vyžádalo tak radikální zásah do současné struktury českého školství, že bychom ji mohli destabilizovat, a že bychom se tedy raději měli pokusit pracovat se dosavadním systémem $v$ malých, na sebe postupně navazujících krocích. Že bychom měli začít například právě tam, kde v reformě školství začaly úspěšné země. U výrazné institucionální a finanční podpory učitelů, která na jedné straně zvýší jejich společenskou prestiž, ale na straně druhé zvýší míru jejich společenské odpovědnosti, a tedy i náročnosti jejich studia a praktické př́pravy.

\section{Závěrem: Poslání}

V předešlých částech jsme sledovali jeden výrazný rys české pedagogické komunity. Ukazovali jsme, jak systémová nespolupráce a nesounáležitost mezi všemi aktéry školské politiky - praktiky a teoretiky, reformátory a úředníky vede $\mathrm{k}$ jejich politické bezvýznamnosti. Tato bezvýznamnost se projevuje v roztř́śštěné a nekoncepční (ne)podpoře aktivit aktérů ze strany státu. Taková nekoncepční (ne)podpora musí přirozeně destabilizovat přípravu a zavádění jakékoli větší změny. Dokumentovali jsme tyto skutečnosti na konkrétním případě - na rozpačitých výsledcích kurikulární reformy. $\mathrm{Na}$ osudu klíčového pojmu reformy - „kompetence“ - zase ukázali, jak příprava a implementace reformy selhává díky neschopnosti intenzivně komunikovat. Tak jsme vykreslili dvě selhání - jedno vnitřní a jedno vnější. Protože aktéři neumějí systémově spolupracovat, jejich společný projekt - proměna českého školství - se zevnitř rozpadá a je pro politiky i veřejnost nepřesvědčivá. A protože aktéři nevyzařují jednotu navenek, nejsou ani pro politiky, ani pro laickou veřejnost dostatečně silnými partnery. Tak se potácejí v začarovaném kruhu, $v$ němž se velká a poctivá práce proměňuje v nepřesvědčivé výsledky a ty zpětně přesvědčují politiky a veřejnost o špatné kondici českého školství, 
tak vzniká hlad po reformách, ty jsou však připravovány zbrkle, rychle a bez dostatečné dlouhodobé podpory politické reprezentace, takže jejich implementace povede opět $\mathrm{k}$ nepřesvědčivým výsledkům a špatnému jménu pedagogické komunity. Vystoupit z tohoto kruhu se nám podaří pouze tehdy, pokud se všichni zmínění aktéři spojí a stanou se významnými partnery v politickém vyjednávání. Ke spojení však nemůže dojít do té doby, dokud aktéři nebudou náležitě vnímat svoji zodpovědnost, která je - chtě nechtě - vyvede z jejich malých ulit.

\section{Literatura}

Brezinka, W. (2001). Východiska k poznání výchovy. Úvod k základi̊m vědy o výchově, $k$ filozofii výchovy a k praktické pedagogice. Brno: L. Marek.

Education statistics - Education spending (\% of GDP) (most recent) by country. In Nation Master. com. Dostupné z http://www.nationmaster.com/graph/edu_edu_spe-education-spendingof-gdp.

Janík, T., Knecht, P., Najvar, P., Píšová, M., \& Slavík, J. (2011). Kurikulární reforma na gymnáziích: výzkumná zjištění a doporučení. Pedagogická orientace, 21(4), 375-415.

Hrubý, D. (2011). Kurikulární reforma přišla pozdě. Pedagogická orientace, 21(4), 474-480.

Klíčové kompetence ve výuce na základní škole a gymnáziu (2011). Dostupné z http://www. vuppraha.cz/wp-content/uploads/2011/07/Klicove_kompetence.pdf.

Kuhn, J. (2011). Kurikulární reforma v poločase. Pedagogická orientace, 21(4), 480-486.

OECD (2011). Lessons from PISA for the United States, atrong performers and successful reformers in education. OECD Publishing. Dostupné z http://dx.doi.org/10.1787/9789264096660en

Pelikán, J. (2012). Státní vzdělávací politika jako významný problém českého školství. Pedagogická orientace, 22(4), 581-595.

Průcha, J. (2012). 20 let České asociace pedagogického výzkumu: historie a výzvy současnosti. Pedagogická orientace, 22(4), 596-607.

Rozpočet kapitoly MŠMT na rok 2010. Dostupné z http://www.msmt.cz/ekonomika-skolstvi/ rozpocet-kapitoly-msmt-na-rok-2010?highlightWords=DMD_kniha2010.

Rozpočet kapitoly MŠMT na rok 2012. Dostupné z http://www.msmt.cz/ekonomika-skolstvi/ rozpocet-kapitoly-msmt-na-rok-2012?highlightWords=Rozpo\%C4\%8Det+kapitoly+M\%C 5\%A0MT+2012.

Spousta, V. (2013). Pokus o modelování bipolarity praktického a teoretického nazírání. Pedagogická orientace, 23(1),112-125.

Šíp, R. (2012). Strach a souboj o kost. Kulturní noviny, 4(11), 5. Dostupné z http://www.kulturninoviny.cz/nezavisle-vydavatelske-a-medialni-druzstvo/ke-stazeni

Štech, S. (2006). Reforma kurikula jako kulturní změna. In V. Zikmundová (Ed.), Rámcový vzdělávací program a výtvarná výchova. Sympozium ČS INSEA Plzeň, 16.-18. ř́ijna 2004 (s. 11-19). Plzeň: Západočeská univerzita Plzeň.

Tupý, J. (2011). Výsledky výzkumu Kvalitní škola z pohledu tvůrce rámcových vzdělávacích programů. Pedagogická orientace, 21(4), 486-492. 